\title{
The Implementation of the 2013 Curriculum of English at SMKN 1 Bantaeng: an Evaluative Study
}

\author{
Ashar \\ cahayapagi037@gmail.com \\ SMKN 4 Bantaeng, Sulsel, Indonesia \\ Irmawati \\ Irmawati_pnup09@yahoo.co.id \\ State Polytechnic of Ujung Pandang, Indonesia
}

\begin{abstract}
The objectives of the research were to obtain a descriptive account of (1) the lesson plans of English language learning based on the 2013 Curriculum at SMKN 1 Bantaeng, (2) learning and assessment process of English language learning based on the 2013 Curriculum at SMKN 1 Bantaeng, (3) supporting factors and obstacles that the English teachers at SMKN 1 Bantaeng face in implementing the 2013 Curriculum of English. The researcher employed descriptive qualitative method. The subjects werefour English teachers of SMKN 1 Bantaeng who participated in this research. All the subjects were selected through purposive sampling. The data of this research were collected by using triangulation technique by combining observation, interview and examining document technique. The obtained data were analyzed in four major phases namely data collecting, data reduction, data display, and conclusion. The result of the research revealed that (1) Lesson plans prepared by English teachers at SMKN 1 Bantaeng were generally well arranged. (2) a. The implementation of English learning process at SMKN 1 Bantaeng based on the 2013 Curriculum still had many shortcomings. The very prominent shortcomings were the aspect of preliminary activities, the implementation of integrated learning, the selection of sources and media, as well as on the closing activities. b. The implementation of assessment process on English learning based on the 2013 Curriculum at SMK 1Bantaengwas not done well, because most of the components of the assessment were not carried out. (3) Supporting factors on the implementation of the 2013 Curriculum of English included (a) the high commitment of the school and government, (b) the distributed guidelines, syllabus, and text book, and (c) the school facilities. Meanwhile the obstacles consisted of (a) the lacking time allocation, (b) the complicated assessment system, and (c) the lack of teachers' understanding on the 2013 Curriculum.
\end{abstract}

Key words: the 2013 Curriculum, ELT plans, practices and assessments,perception.

\section{INTRODUCTION}

In the history of education in Indonesia, curriculum has been modified and refined several times.

In the academic year 2006/2007, the government through the Ministry of National Education defined the 2006 Curriculum (KTSP) at each level of education as a replacement for the previous curriculum, which is known as the 2004 Curriculum/Competency Based Curriculum (CBC). 
Ashar, Irmawati: The Implementation of the ... $\mid 157$

Have been applied for seven years, the 2006 Curriculum (KTSP) was replaced by the 2013 Curriculum. In the academic year 2013/2014, the 2013 Curriculum is implemented in 6221 piloting schools, and then will be implemented by all schools in Indonesia for the academic year $2014 / 2015$.

However, after less than two years, the implementation of the 2013 Curriculum is suspended with the purpose of evaluation and improvement of the Curriculum. In Permendikbud RI No 160, 2014 about the Enforcement Of the 2006 Curriculum (KTSP) and the 2013 Curriculum, it is stated that especially for schools that have implemented the 2013 Curriculum since the academic year 2014/2015, the implementation of the curriculum will be stopped and the 2006 Curriculum (KTSP) will be re-implemented. At the same time, piloting schools are encouraged to continue the implementation of the 2013 Curriculum.

Related to English subjects as one of important components in the spectrum of the 2013 curriculum, it has a goal to develop the ability of students to communicate in that language, with communication skills that include the ability to listen, speak, read, and write. In the spectrum of curriculum, English subject for SMK is an adaptive subject, which is aimed to prepare students to master the knowledge and skills of basic English that will support skills competence achievement in the program of study, and to apply the mastery of English skills in oral and written communication on advanced level (Permendikbud No. 64, 2013).

The implementation of the 2013 Curriculum has been running effectively for about 3 years.Based on this fact it can be said that the curriculum was still relatively new, and teachers' understanding about the 2013 Curriculum in general was still limited. So it is reasonable when the debate surrounding the curriculum was still emerging, both in terms of advantages and disadvantages, as well as the constraints faced by teachers in implementing it. Such conditions could be found in almost all schools, including at SMKN 1 Bantaeng.Therefore, the researcher believed that the study on the implementation of the 2013 Curriculum in English learning at SMKN 1 Bantaeng is important to do.

\section{METHOD}

In this research, the researcher applied a qualitative research design. This was employed to investigate deeply about the implementation of the 2013 Curriculum of English. In keeping with the focus of the problems that had been formulated, the approach in this study was an evaluative approach on the implementation of the 2013 Curriculum of English learning particularly at SMKN 1 Bantaeng. 
158| ELT Worldwide Vol. 3 No. 2 October 2016

To obtain more in-depth and comprehensive description toward the implementation of the 2013 Curriculum on English learning, this study applied the case study method with a qualitative evaluative approach.The subjects of this research were all English teachers of SMKN 1 Bantaeng with the total number was four (4) teachers. The subjects were determined by the intention to obtain information through interviews and observations.

\section{Data Collection Technique}

In conducting this research, the researcher applied triangulation technique by combining observation, interview and examining document technique. In observation, the researcher attended the class and observed the learning and teaching process directly while filled the observation checklist. In interview session, the researcher gave some questions in relation to the teachers feeling and though toward the 2013 implementation.For both these techniques was supported by the video recording during the class to keep the consistency of the data.Examining documents technique was conducted by the researcher to obtain more information or data concerning to the lesson plan and learning assessment undertaken by the teachers. It was also useful to complete the information that has been obtained through observation technique.

In this case, the researcher used descriptive analysis technique. The analysis was in the form of words or paragraphs to be stated in the form of a descriptive narrative on real events that occurred in the study site. Meanwhile, activities in the analysis of the data consisted of: data collection, data reduction, data display, and conclusion drawing/verification. The format of the research instrument used observation checklist or rating scale then described by descriptive analysis. It was intended to support the analysis of the data so it could be easily to understand the extent of the implementation of the 2013 Curriculum when viewed from various standards on the terms of the 2013 Curriculum at SMKN 1 Bantaeng.

The maximum rate for each variable was obtained by the formula:

Table 1. Maximum rate for each instrument

\begin{tabular}{clccc}
\hline No & Variable & $\begin{array}{c}\text { The } \\
\text { Maximum } \\
\text { rate for } \\
\text { Each } \\
\text { Indicator }\end{array}$ & $\begin{array}{c}\text { Number of } \\
\text { Indicator }\end{array}$ & $\begin{array}{c}\text { The } \\
\text { Maximum } \\
\text { Rate }\end{array}$ \\
\hline 1 & Lesson Plan & 3 & 37 & 111 \\
2 & $\begin{array}{l}\text { Learning Process } \\
3\end{array}$ & 3 & 32 & 96 \\
Learning & Assessment & 1 & 15 & 15 \\
\hline
\end{tabular}


Ashar, Irmawati: The Implementation of the ... 159

Table2.Rating criteria

\begin{tabular}{|c|c|c|}
\hline Rate & State Description & Remarks \\
\hline \multicolumn{3}{|c|}{ Study on Lesson Plan Document } \\
\hline 3 & Appropriate & $\begin{array}{l}\text { Components of arranged lesson plans were } \\
\text { appropriate with the indicator }\end{array}$ \\
\hline 2 & Partially appropriate & $\begin{array}{l}\text { Some of arranged lesson plans' } \\
\text { components were not appropriate with the } \\
\text { indicator }\end{array}$ \\
\hline 1 & Nothing/Not appropriate & $\begin{array}{l}\text { The components of lesson plans were not } \\
\text { listed/All the components of the arranged } \\
\text { lesson plans were not appropriate with the } \\
\text { indicator. }\end{array}$ \\
\hline \multicolumn{3}{|c|}{ Observation on Learning Process } \\
\hline 3 & Complete & $\begin{array}{l}\text { Required learning activities were } \\
\text { completely done }\end{array}$ \\
\hline 2 & Incomplete & $\begin{array}{l}\text { Required learning activities were partially } \\
\text { done }\end{array}$ \\
\hline 1 & Nothing/Not appropriate & $\begin{array}{l}\text { All required learning activities were not } \\
\text { done/ All required learning activities were } \\
\text { not appropriate }\end{array}$ \\
\hline \multicolumn{3}{|c|}{ Study on Assessment Document } \\
\hline 1 & Available & Assessment document can be accessed \\
\hline 0 & Not Available & Assessment document cannot be accessed \\
\hline
\end{tabular}

The rating scale category applied formula:

Table 3.Rating scale criteria

\begin{tabular}{cc}
\hline Rating & Scale \\
$\%$ \\
\hline Very Good (VG) & $91<\mathrm{VG} \leq 100$ \\
Good (G) & $81<\mathrm{G} \leq 90$ \\
Fair (F) & $71<\mathrm{F} \leq 80$ \\
Poor (P) & $\mathrm{P} \leq 70$
\end{tabular}

Adapted from http://pengawassekolahjombang.blogspot.co.id, 2015

\section{FINDINGS AND DISCUSSIONS}

\section{English Teachers' Lesson Plan Based on the 2013 Curriculum}

The following table shows the average value of the degree of suitability of lesson plans' indicator of 4 English teachers studied. 
160| ELT Worldwide Vol. 3 No. 2 October 2016

Table 4.Average achievement of lesson plans' indicators.

\begin{tabular}{clccccc}
\hline \multirow{2}{*}{ No. } & \multicolumn{1}{c}{ Indicators } & T. 1 & T. 2 & T. 3 & T. 4 & Ts. \\
\hline 1. & Identity of subject & 100 & 100 & 87 & 100 & 97 \\
2. & Formulation of indicators & 100 & 100 & 100 & 100 & 100 \\
$\mathbf{3}$ & Formulation of learning objectives & $\mathbf{6 7}$ & $\mathbf{1 0 0}$ & $\mathbf{3 3}$ & $\mathbf{1 0 0}$ & $\mathbf{7 5}$ \\
4. & Selection of teaching materials & 100 & 83 & 50 & 83 & 79 \\
$\mathbf{5 .}$ & Selection of learning resources & $\mathbf{6 7}$ & $\mathbf{9 2}$ & $\mathbf{3 3}$ & $\mathbf{9 2}$ & $\mathbf{7 1}$ \\
6. & Selection of larning medium & 100 & 100 & 33 & 89 & 81 \\
$\mathbf{7 .}$ & Learning model & $\mathbf{8 3}$ & $\mathbf{1 0 0}$ & $\mathbf{3 3}$ & $\mathbf{6 7}$ & $\mathbf{7 1}$ \\
8. & Learning scenario & 89 & 83 & 78 & 78 & 82 \\
9 & Assessment & 100 & 100 & 100 & 100 & 100 \\
\hline & The average percentage scale & 90 & 95 & 61 & 90 & $\mathbf{8 4}$ \\
\hline
\end{tabular}

*) T.1 (Teacher 1), T.2 (Teacher 2), T. 3 (Teacher 3), T. 4 (Teacher 4), Ts. (Teachers)

Table 4 shows that the average percentage scale of indicators conformity of the lesson plans of English teacher at SMK 1Bantaeng reached $84 \%$. It meant that lesson plans that prepared by the Teachers in these schools were categorized Good. But in general, there were three indicators which show low average percentage scale. The three indicators were the formulation of the learning objectives (75\%), selection learning resources (71), and learning models (71).

Based on the research data, the low level of conformity of those indicators due to the preparation of learning objectives did not include all the basic competence $(K D)$, or did not refer to the indicator. In Permendikbud No. 81A, 2013 stated that the learning objectives are organized covering all basic competencies (KD) or organized for each meeting. And the purpose refers to the indicator.

In terms of the selection of learning resources, in general English teacher at SMKN 1 Bantaeng set textbooks as a major source of learning. Even in some of the planning, textbooks being the only source of learning. Whereas in Permendikbud No. 81A, 2013 explained that learning resources are references, objects and/or materials used for learning activities, in the form of printed and electronic media, resource persons, as well as the physical environment, nature, social, and cultural.

Last, related to the learning models, based on the results of the research lecturing model was still the main choice of the most studied lesson plans. Though there were many kinds of learning model to choose from. 


\section{Ashar, Irmawati: The Implementation of the ... |161}

In English Language Curriculum Training Guidelines, 2013, written several instructional models to choose, namely inquiry based learning, discovery-based learning, project based learning, and problem based learning.

\section{English Teachers Learning and Assessment Process Based on the 2013 Curriculum}

a. English learning based on the 2013 Curriculum at SMKN 1 Bantaeng.

Table 4.18. The average percentage scale of the learning process

\begin{tabular}{|c|c|c|c|c|c|c|}
\hline No. & Aspects Observed & T. 1 & T. 2 & $\begin{array}{c}\text { T. } 3 \\
\%\end{array}$ & T. 4 & $\begin{array}{l}\text { Ts. } \\
\%\end{array}$ \\
\hline \multicolumn{7}{|c|}{ Preliminary Activity } \\
\hline 1. & Apperception and motivation & 56 & 67 & 67 & 44 & 59 \\
\hline 2. & Delivery of competence and activity plan & 33 & 67 & 67 & 67 & 59 \\
\hline \multicolumn{7}{|c|}{ Core Activity } \\
\hline 3. & Mastery of learning materials & 89 & 78 & 67 & 78 & 78 \\
\hline 4. & The implementation of learning strategies & 67 & 92 & 83 & 83 & 81 \\
\hline 5. & $\begin{array}{l}\text { The implementation of scientific } \\
\text { approach }\end{array}$ & 80 & 87 & 87 & 87 & 85 \\
\hline 6. & $\begin{array}{l}\text { The implementation of integrated } \\
\text { learning }\end{array}$ & 56 & 89 & 56 & 78 & 70 \\
\hline 7. & $\begin{array}{l}\text { The use of learning resources / media in } \\
\text { learning }\end{array}$ & 67 & 67 & 67 & 67 & 67 \\
\hline \multirow[t]{3}{*}{8.} & The involvement of students in learning & 73 & 100 & 80 & 87 & 85 \\
\hline & Closing Activity & 50 & 92 & 50 & 50 & 61 \\
\hline & Average & 64 & 82 & 69 & 71 & 72 \\
\hline
\end{tabular}

*) T.1 (teacher 1), T.2 (teacher 2), T. 3 (teacher 3), T. 4 (teacher 4), Ts. (teachers)

From the data presented in the table 4.18 , it is shown that in the preliminary activities Teacher 1, 2, 3, and 4 were not conducting apperception and motivation well. So the average scale of the achievement only reached 59\%. Similarly with the delivery of learning competencies and planned learning activities that were not carried out by the teachers, so the average scale of the achievement only reached $59 \%$. 
162| ELT Worldwide Vol. 3 No. 2 October 2016

Activities conducted by the teachers in the preliminary activity gave a great influence on a learning activity afterwards. So the teachers' attempt to raise students' motivation, create a warm learning atmosphere, create fun learning environment, convey competence to be achieved, as well as the learning agenda, needed to be implemented at the beginning of learning process. In Permendikbud No. 103, 2013 stated that in the preliminary activities, the task of a teacher is condition learning fun environment, discussing the competence that has been and will be studied, as well as conveying scope of material and activities to be carried out. Therefore, it was important for teachers to prepare learning environment at the beginning of the activity, so students feel comfortable and motivated to learn.

At the core activities, Teacher 1 had good mastery of learning material with percentage scale $89 \%$, Teacher 2 and 4 had a sufficient mastery of learning material with percentage scale $78 \%$, while Teacher 3 had lack mastery of learning materials with percentage scale $67 \%$. In general, the teachers showed sufficient mastery of learning material with average percentage scale $78 \%$. Therefore, it was concluded that the mastery of learning materials needs to be improved. Based on the findings, the low achievement of the mastery of the learning material due to the teachers did not associate the learning material with the other knowledge, or with the daily life. In Permendikbud No. 65 stated that learning is directed at the development of science and technology, and real life. Therefore, it was necessary to associate the English language learning materials with the other knowledge, as well as real life.

Furthermore, related to the implementation of learning strategies, Teacher 2, 3, and 4 obtained percentage scale above $83 \%$ with good category. Meanwhile Teacher 1 only obtained percentage scale $67 \%$ with Poor category. Based on the findings, it was shown that the achievement of percentage scale of teachers was affected by three indicators. The first was the ability of teachers to conduct exploration activities, the second was the ability of teachers to perform contextual learning, and the third was the ability of teachers to implement learning in accordance with the allocation of time. These three indicators were an important part of a learning process because it directly influenced the students' learning process. For example, in the exploration activity it was important for students to be given the opportunity to develop creativity, actively involved in the learning, experimenting and searching for material and information from various sources. To find more in-depth explanation of the three indicators, we can see Permendikbud No. 81A, 2013, on Curriculum Implementation. 
Ashar, Irmawati: The Implementation of the ... 163

In the case of the scientific approach implementation, even though the average percentage scale was not $100 \%$, but the degree of compliance shown by teachers was quite satisfying with an average scale of $85 \%$. Related to the implementation of integrated learning, there were two things that were often ignored by the teachers throughout the learning process. The first was the effort of teachers in associating learning materials with the character components. The second was a fun learning presentation by the teacher. To achieve the quality of learning, learning activities need to use principles: (1) centered on the learner, (2) developing the creativity of learners, (3) create conditions fun and challenging, (4) loaded with values, ethics, aesthetics, logic, and kinestetika, and (5) provide a diverse learning experience through the application of various strategies and methods of fun, contextual, effective, efficient, and meaningful learning (Permendikbud No. 81A, 2013).

Furthermore, based on the findings, there was a fact that in terms of resource usage and the use of learning media, it seemed that teachers tended to use textbooks as the source and the blackboard as a medium of learning. From the observation, it appeared that the teachers lack the initiative to seek learning materials from other sources. So the scale of the indicators only reached $67 \%$ or categorized Poor. In Permendikbud No. 65, 2013 and Permendikbud No. 81A, 2013 stated that the learning resources may include books, printed and electronic media, the environment, or other relevant learning resources. Likewise, the media can be anything as long as it can help and relevant to the learning materials. Therefore, teachers should be able to have a lot of alternatives in terms of selecting the source and medium of learning.

Regarding the involvement of students in learning, in Permendikbud No. 81A, 2013 explained that in learning, learners are facilitated to engage actively develop their potential. Teachers provide learning experiences for learners to perform various activities that allow them to develop their potential. Based on the research data, it was concluded that the involvement of students by Teacher 1, 2, 3, and 4 in learning was quite well.

The last discussion in this section related to the closing activities. Based on the findings, Teacher 2 closed the learning activities well, with the scale of the achievement $92 \%$. Meanwhile the closing activities undertaken by teachers 1,3 , and 4 only reached $50 \%$. The low achievement of Teacher 1,3 , and 4 in closing activity were caused by several indicators that were not carried out. Teachers concluded learning material without involving students, teachers did not collect the portfolio, and the teachers did not provide guidance for further activity or for the next meeting. 
164| ELT Worldwide Vol. 3 No. 2 October 2016

In Permendikbud No. 65, 2013 stated that the activities of closing activity consist of 1 . Joint activities between teachers and learners namely: (a) summarizing/concluding lesson; (b) reflect the activities that have been implemented; and (c) provide feedback of the process and learning outcomes; 2. The activities of teachers, namely: (a) conduct an assessment; (b) plan follow-up activities in the form of remedial, enrichment programs, counseling services and / or provide individual and group tasks in accordance with the learning outcomes of students; and (c) convey lesson plans for the next meeting.

Referring to the data in the table 4.23, it is shown that the assessment indicators that were owned and carried out by Teacher $1,2,3$, and 4 were generally the same. Although Teacher 2 carried out more assessments, but the difference was not too significant.

\section{Assessment of English Learning Process Based on the 2013 Curriculum}

Table 4.23. The average scale of English learning assessment carried out by the Teachers.

\begin{tabular}{|c|c|c|c|c|c|c|}
\hline No. & Assessment & $\begin{array}{c}\text { T. } 1 \\
\%\end{array}$ & $\begin{array}{c}\text { T. } 2 \\
\%\end{array}$ & $\begin{array}{l}\text { T. } 3 \\
\%\end{array}$ & $\begin{array}{c}\text { T. } 4 \\
\%\end{array}$ & $\begin{array}{l}\text { Ts. } \\
\%\end{array}$ \\
\hline \multirow[t]{2}{*}{1.} & Assessment book & 0 & 0 & 0 & 0 & 0 \\
\hline & Test Conducted & & & & & \\
\hline 2. & Daily test & 0 & 100 & 0 & 0 & 25 \\
\hline 3. & Mid-term test & 100 & 100 & 100 & 100 & 100 \\
\hline \multirow[t]{2}{*}{4.} & Semester Test & 100 & 100 & 100 & 100 & 100 \\
\hline & $\begin{array}{l}\text { Assessment of Attitude } \\
\text { Competence }\end{array}$ & & & & & \\
\hline 5. & Observation & 0 & 0 & 0 & 0 & 0 \\
\hline 6. & Self-assessment & 0 & 0 & 0 & 0 & 0 \\
\hline 7. & Assessment among learners & 0 & 0 & 0 & 0 & 0 \\
\hline \multirow[t]{2}{*}{8.} & Journal & 0 & 0 & 0 & 0 & 0 \\
\hline & $\begin{array}{l}\text { Assessment of Knowledge } \\
\text { Competence }\end{array}$ & & & & & \\
\hline 9. & Written test & 100 & 100 & 100 & 100 & 100 \\
\hline 10. & Oral test & 0 & 0 & 0 & 0 & 0 \\
\hline \multirow[t]{2}{*}{11.} & Assignment & 100 & 100 & 100 & 100 & 100 \\
\hline & Assessment of Skills Competence & & & & & \\
\hline 12. & Practice test & 0 & 0 & 0 & 0 & 0 \\
\hline 13. & Project & 0 & 0 & 0 & 0 & 0 \\
\hline 14. & Portfolio & 0 & 100 & 0 & 0 & 25 \\
\hline \multirow[t]{2}{*}{15.} & Analisys of test result & 100 & 100 & 100 & 100 & 100 \\
\hline & Average & 33 & 47 & 33 & 33 & 37 \\
\hline
\end{tabular}

*) T.1 (teacher 1), T.2 (teacher 2), T. 3 (teacher 3), T. 4 (teacher 4), Ts. (teachers) 
Assessment indicators that were owned and carried out by teachers 1, 2, 3 , and 4 included midterm tests, the semester test, written test, assignment, and analysis of the test result. While the indicators that were not owned and implemented by the teachers included assessment book, observation, self assessment, assessment among learners, journal, oral test, practice test, project, and portfolio.

When compared to the number of assessment indicators that were not implemented, it would be obtained a big difference. Generally there were five assessment indicators were carried out, while there were 10 indicators that were not implemented. When using a percentage scale, the assessment indicators carried out by teachers 1, 2, 3, and 4 only reached $37 \%$. Such conditions provided a picture that diverged from its ideal form.

Referring to Permendikbud No. 66, 2013, Permendikbud No. 81A, 2013, and Assessment Guide of Learner's Competence Achievement for vocational high school in 2013 (Panduan Penilaian Pencapaian Kompetensi Peserta Didik SMK. 2013), then for schools that implement the 2013 Curriculum should implement the 15 indicators of learning assessment.

\section{Factors and Obstacles that English Teachers Faced in Implementing the 2013 Curriculum}

In general, English teacher at SMKN 1 Bantaeng identifed the same supporting factors and obstacles in implementing the 2013 Curriculum. The supporting factors identified were as follows:

1) Socialization, guidance, and training had been conducted by the school and government.

2) Guidelines for the implementation of the 2013 curriculum were distributed to every teacher.

3) Textbooks as learning resources were distributed by the government.

4) School facilities were sufficiently available.

5) Each teacher gained the syllabus and guidelines for preparing lesson plans.

The obstacles identified were as follows:

1) Allocation of time for English subject was only 2 hours for each meeting (lacking).

2) The scoring system was complicated, a lot, and difficult to apply. 
166| ELT Worldwide Vol. 3 No. 2 October 2016

3) Lower conformity between the materials contained in textbook and in the syllabus.

4) Competence to be achieved in each lesson was too many.

5) It was difficult to choose appropriate method of learning based on the 2013 Curriculum due to the low level of English knowledge of students.

6) Teachers' understanding about the 2013 Curriculum was still lacking, especially in the assessment system.

\section{Conclusion}

Based on the findings and discussion in the previous chapter about lesson plan, learning and assessment process based on the 2013 Curriculum of English, and supporting factors and obstacles that the English teachers at SMKN 1 Bantaeng face in implementing the 2013 Curriculum of English, the researcher puts forward the conclusions that lesson plans prepared by English teachers at SMKN 1 Bantaeng were generally well arranged, and most of the components in it were in accordance with the indicators set by the government. But there were a few aspects of the preparation which were not been as expected. The researcher looked at these aspects from two perspectives. The first was in terms of teachers. From the four English teachers studied, one of them had a lesson plan in which there were still many shortcomings. The second was in terms of the components of lesson plan. Three components of learning plans obtained the lowest percentage scale. The components were the formulation of learning objectives, selection of learning resources, and learning model.

The implementation of English learning process at SMKN 1 Bantaeng based on the 2013 Curriculum still had many shortcomings. The very prominent shortcomings were the aspect of preliminary activities, the implementation of integrated learning, the selection of sources and media, as well as on the closing activities. The low-scale fulfillment of the indicators due to the understanding of the teachers which did not complete, for the reason that the 2013 Curriculum was still new for them.

The implementation of assessment process on English learning based on the 2013 Curriculum at SMK 1 Bantaeng did not run well. From the fifteen components of the assessment to be carried out, on average, each teacher only carried out five assessment indicators. Referring to the result of interview, the situation was in line with the complaints of these teachers. All of them complained the assessment system of the 2013 Curriculum. They assumed that the assessment system was too many, complicated, time consuming, and difficult to apply. 
Ashar, Irmawati: The Implementation of the ... 167

There were supporting and inhibiting factors on the implementation of the 2013 Curriculum. The supporting factors on the implementation of the 2013 Curriculum on English language learning were (1) the high commitment of both the school and the government by conducting intensive coaching and training, (2) each teacher had guidelines for the implementation of the 2013 Curriculum, and text book as a learning resources, (3) school facilities sufficiently support, and 4) each teacher obtained syllabus and draft for the lesson plan preparation. Meanwhile the inhibiting factors were (1) the allocation of time that only consisted 2 x 45 minutes (two hours for each lesson), (2) the complicated assessment system, (3) the material contained in the distributed text books did not fully comply with the competence to be achieved, (4) the number of competencies to be achieved in each lesson were too many, (5) it was difficult to choose the learning method in accordance with the level of students 'knowledge of English language, (6) teachers' understanding on the 2013 Curriculum was still lacking, especially in the assessment system.

\section{REFERENCE}

Ahmad, Djuwairiah. 2014. Understanding the 2013 Curriculum of English Teaching through the Teachers" and Policymakers" Perspectives: International Journal of Enhanced Research in Educational Development (IJERED). Vol. 2, Issue 4, JulyAugust, 2014, pp: (6-15).www.erpublications.com. Retrieved on $28 / 03 / 2015$.

Asih M. F. (2014). ImplementasiKurikulum 2013 pada Mata Pelajaran IPS di SekolahMenengahPertama (SMP) Negeri 1 Blado.Semarang. JurnalPendidikanEkonomi IKIP Veteran Semarang. Vol. 2 No. 1, November 2014. Retrieved on 21/03/2015.

Direktorat Pembinaan SMA/SMK-Ditjen Pendidikan Menengah. 2014.

Fahrawaty. 2014. Bahasa Inggris Sebagai Bahasa Internasional dan Pengaruhnya Terhadap Kurikulum Pembelajaran Bahasa Inggris di Indonesia. www.lpmpsulsel.net. Retrieved on $11 / 07 / 2015$.

Gay, L.R. 2006. Educational research: Competencies for analysis and application (2nd ed.). Columbus, OH: Charles E. Merrill Publishing Company. 
168| ELT Worldwide Vol. 3 No. 2 October 2016

Kamus Besar Bahasa Indonesia Online. http://kbbi.web.id/kurikulum. Retrieved on 07/07/2015.

Kementerian Pendidikan dan Kebudayaan. 2013. PedomanPelatihan Implementasi Kurikulum 2013. Jakarta: BPSDMPK-PMP.

Mulyasa, E. 2013. Pengembangan dan Implementasi Kurikulum 2013. Bandung: PT. Remaja Rosdakarya.

Muzamiroh, L, M. 2013. Kupas Tuntas Kurikulum 2013; Kelebihan dan Kekurangan Kurikulum 2013. Jakarta: Kata Pena.

Nasution, S. 1988. Metode Penelitian Naturalistik Kualitatif. Bandung: Tarsito.

Nunan, D. 1988. Syllabus Design. Oxford: Oxford University Press.

Overton, Terry. 2008. Assessing Learners with Special Needs: An Applied Approach (7th Edition). University of Texas Brownsville.

PermendikbudRI No. 54 tahun 2013 tentang Standar Kompetensi Lulusan.

Permendikbud RI No. 64 Tahun 2013 tentang Standar Isi Pendidikan Dasar Dan Menengah.

Permendikbud RI No. 65 tahun 2013 tentang Standar Proses Pendidikan Dasar dan Menengah.

Permendikbud RI No. 66 Tahun 2013 Tentang Standar Penilaian Pendidikan.

Permendikbud RI No. 70 Tahun 2013 Tentang Kerangka Dasar Dan Struktur Kurikulum Sekolah Menengah Kejuruan/Madrasah Aliyah Kejuruan.

Permendikbud RI No. 81a Tahun 2013 Tentang Implementasi Kurikulum.

Permendikbud RI No. 103 tahun 2014 tentang Pembelajaran Pada Pendidikan Dasar dan Pendidikan Menengah.

Permendikbud RI No. 160 Tahun 2014 Tentang Pemberlakuan Kurikulum Tahun 2006 Dan Kurikulum 2013. 
Ashar, Irmawati: The Implementation of the ... |169

Said, Hasbullah and Yusof, Sanitah. 2014. Assessing the Implementation Of Curriculum - 2013 For Teaching English Subject In Islamic Secondary Schools : Using Delphi Approach. Universiti Teknologi Malaysia. Vol . 4, No. 1. Retrieved on 10/04/2015.

Sugiyono. 2014. Metode Penelitian Kombinasi (Mixed Methods). Bandung. CV. Alfabeta.

Undang Undang 20 tahun 2003 tentang Sistem Pendidikan Nasional.

Uno, Hamzah B. 2009. Perencanaan Pembelajaran. Jakarta: PT Bumi Aksara.

http://www.republika.co.id/berita/kemendikbud/beritakemendikbud/14/12/08/ng9bi6-seputar-keputusan-mendikbudtentang-penghentian-kurikulum-2013. Retrieved on 21/03/2015.

http://pengawassekolahjombang.blogspot.co.id/2013/12/instrumentelaah-rpp-dan-penilaian.html. Retrieved on 20/10/2015. 